\title{
Influence of reactivity and mineralogical composition on instability due to the disintegration of shales from Paraíba and Ceará States, Brazil
}

\section{(Influência da reatividade e composição mineralógica na instabilidade por desintegração de folhelhos dos estados da Paraíba e Ceará, Brasil)}

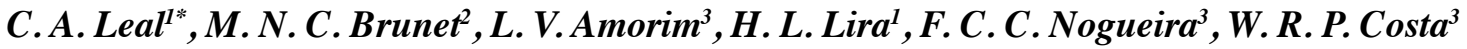 \\ ${ }^{1}$ Universidade Federal de Campina Grande, Programa de Pós-Graduação em Ciência e \\ Engenharia de Materiais, Campina Grande, PB, Brazil \\ ${ }^{2}$ Universidade Federal de Pernambuco, Programa de Pós-Graduação em Engenharia Civil, Recife, PE, Brazil \\ ${ }^{3}$ Universidade Federal de Campina Grande, Unidade Acadêmica de Engenharia de Petróleo, \\ Campina Grande, PB, Brazil
}

\begin{abstract}
This work aimed to correlate the reactivity and mineralogical composition of shales to their disintegration. To accomplish this, five samples of shale from Rio do Peixe Basin and Araripe Basin, located in the Brazilian States of Paraíba and Ceará, respectively, were characterized. A sample of industrialized bentonite clay was used as a reference to provide a comparison. Characterization was performed through cation exchange capacity, particle size analysis, X-ray fluorescence, and X-ray diffraction. Disintegration tests were performed according to the American Petroleum Institute standards in the presence of deionized water, aqueous potassium citrate solution, and drilling fluid. The results suggested that samples presenting no reactive clay mineral content may be unstable and the higher the reactivity of the samples to aqueous fluids does not necessarily imply a higher level of disintegration. This demonstrated that different mechanisms not associated with clay swelling may assume greater or lesser relevance on the instability of a formation.
\end{abstract}

Keywords: shales, disintegration, well instability.

Resumo

Este trabalho teve como objetivo correlacionar a reatividade e composição mineralógica de folhelhos à sua desintegração. Para tanto, foram caracterizadas cinco amostras de folhelho das Bacias do Rio do Peixe e Araripe, localizadas nos estados brasileiros da Paraíba e Ceará e, para fins de comparação, foi utilizada uma amostra de argila bentonítica industrializada. A caracterização foi realizada por capacidade de troca de cátions, analise granulométrica, fluorescência de raios $X$ e difração de raios X. Também foram realizados testes de desintegração, de acordo com as normas API (American Petroleum Institute), na presença de água deionizada, solução aquosa de citrato de potássio e fluido de perfuração. Os resultados sugeriram que formações que não apresentam argilominerais reativos podem ser instáveis e que a maior reatividade das formações frente a fluidos aquosos não implica, necessariamente, em maior nível de desintegração, mostrando assim que diferentes mecanismos não associados ao inchamento dos argilominerais podem assumir maior ou menor importância na instabilidade da formação.

Palavras-chave: folhelhos, desintegração, instabilidade de poços.

\section{INTRODUCTION}

Shale is a sedimentary rock of fine granulometry composed predominantly of clay minerals (kaolinite, illite, smectite, etc.) and other minerals such as quartz and feldspar $[1,2]$. Shale makes up approximately $75 \%$ of drilled formations and is related to more than $90 \%$ of the instability problems of oil wells, which cost between $\$ 500$ - 1000 million USD per year to the oil industry [3,4]. The instability of oil wells may be explained as an undesired condition in

*caline_leal@hotmail.com

(D) https://orcid.org/0000-0002-4929-9096 which the well does not maintain its diameter, shape and/ or structural integrity. This can result in several problems including difficulties in cleaning and maintenance, increase or decrease in the well diameter, and loss of circulation [5]. Additional problems, such as bit balling and disintegration of cuttings, may occur during drilling of shale formations using aqueous fluids. These issues lead to unstable behavior of the well and may cause the abandonment of certain regions, or in extreme cases, of the entire well [6].

Hydration and subsequent swelling of the clay minerals present in shales lead to an increase in interlayer spacing and is historically the main cause attributed to the instability of these formations [7]. The swelling of clay minerals can 
follow two mechanisms: crystalline and osmotic swelling. Crystalline swelling is a common process that can occur in all types of clay minerals and is related to an increase of the interlamellar spacing due to hydration, typically in the range of 9 to $20 \AA$ A . Osmotic swelling occurs only to specific clay minerals and causes a significant increase of the interlayer spacing, generally in the range of 20 to $130 \AA$ [8]. The major difference in the behavior of these clays is attributed to its composition which determines its affinity for water [9]. Shales rich in smectite, which has a high cation exchange capacity and specific surface area, should have a higher affinity for water than shales with greater amounts of illite or kaolinite, which have a significantly lower cation exchange capacity and specific surface area [10].

The swelling of clay minerals creates a tensile force in the shale, causing the separation of layers and the consequent weakening of the clay [11]. However, according to Van Oort [11], other factors, which are not directly related to the swelling of clay minerals, such as pore pressure, may influence the instability of these clays. According to Wilson and Wilson [6], some shales containing expressive amounts of clay minerals such as illite, which do not present high levels of swelling, may also have unstable behavior during drilling operations. In recent studies, Wilson et al. [12] argue that structural features in illite clay minerals, unrelated to swelling, may have particular influence in the instability of shale formations. This shows that clay-mineral swelling is certainly important but not the main mechanism of its instability. This work aims to correlate the reactivity and mineralogical composition of shales to their instability due to disintegration.

\section{EXPERIMENTAL}

Five samples of shale were selected from the Araripe and Rio do Peixe Basins located in Northeastern Brazil. These sedimentary deposits are from the Cretaceous period and were deposited by continental environments of the lacustrine type. The samples collected in Rio do Peixe Basin were composed of red and green shales, while those collected in the Araripe Basin were gray and black. These samples were obtained in outcrops and were considered analogous to the shales present in several wells that present problems of disintegration during drilling. The shale samples are identified in Table I. A sample of industrially activated sodium bentonite (SB) clay was also used.

The determination of the cation exchange capacity (CEC) and the specific surface area (SSA) of the samples was performed using the adsorption of methylene blue. For this technique, initially, $0.5 \mathrm{~g}$ of the shale sample was milled and sieved in an ABNT No. 200 sieve. After that, the sample was slowly mixed with $300 \mathrm{~mL}$ of deionized water with the mixture being continually stirred. A pH meter was inserted in the suspension and $1 \mathrm{~N}$ of $\mathrm{Na}_{2} \mathrm{CO}_{3}$ solution was added dropwise until the suspension reached a $\mathrm{pH}$ equal to 9.0. Then, $1 \mathrm{~N}$ of $\mathrm{HCl}$ was added dropwise until the solution reached a $\mathrm{pH}$ equal to 3.5. After the $\mathrm{pH}$ stabilized to 3.5, 2 $\mathrm{mL}$ of an aqueous methylene blue solution $(3.7 \mathrm{~g} / \mathrm{L})$ was
Table I - Nomenclature and location of shale samples. [Tabela I - Nomenclatura e localização das amostras de folhelho.]

\begin{tabular}{|c|c|c|}
\hline Sample & Nomenclature & Location \\
\hline Shale 1 & S1 & $\begin{array}{c}\text { Rio do Peixe Basin, } \\
\text { Sousa-PB }\end{array}$ \\
\hline Shale 2 & $\mathrm{~S} 2$ & $\begin{array}{c}\text { Araripe Basin, Nova } \\
\text { Olinda-CE }\end{array}$ \\
\hline Shale 3 & S3 & $\begin{array}{c}\text { Araripe Basin, Nova } \\
\text { Olinda-CE }\end{array}$ \\
\hline Shale 4 & S4 & $\begin{array}{c}\text { Araripe Basin, Nova } \\
\text { Olinda-CE }\end{array}$ \\
\hline Shale 5 & S5 & $\begin{array}{c}\text { Rio do Peixe Basin, } \\
\text { Sousa-PB }\end{array}$ \\
\hline
\end{tabular}

added to the mixture and after 5 min a drop of the mixture was placed on a filter paper (Whatman, TM Cat. 1450090, $2.7 \mu \mathrm{m}$ pore size). The formation of a very intense bluish circular crown appeared on the filter paper after 15 min, after which another drop was added to confirm that all the cations were adsorbed, ending the test. Otherwise, $2 \mathrm{~mL}$ of methylene blue was added and after 5 min another drop was dripped onto the filter paper until the previously described phenomenon occurred. Knowing the total volume (V) of methylene blue used to form the very intense bluish circular crown, the molar concentration of the solution (C), approximately $3.7 \mathrm{~g} / \mathrm{L}$, and the sample mass $(\mathrm{m})$ of $0.5 \mathrm{~g}$, the cation exchange capacity (CEC) and the specific surface area (SSA) were calculated by:

$$
\begin{aligned}
\mathrm{CEC} & =\frac{\mathrm{C} \cdot \mathrm{V} \cdot 100 \mathrm{~g}}{\mathrm{~m}}=\left(\frac{\mathrm{meq} \text { of blue methylene }}{100 \mathrm{~g} \text { of dry clay }}\right) \\
\mathrm{SSA} & =\mathrm{CECx} 7.8043\left(\frac{\mathrm{m}^{2}}{\mathrm{~g}}\right)
\end{aligned}
$$

The granulometric analyses (GA) of the shale samples were made to determine the particle size distribution by laser diffraction using a Cilas 1064. The chemical composition was determined by X-ray fluorescence (XRF) using the semiquantitative method under a nitrogen atmosphere in the Shimadzu EDX-720. X-ray diffraction (XRD) was used to qualitatively identify the mineralogical constituents of the samples, which is widely used for the characterization of crystalline structures. XRD analyses were performed on an X-ray diffraction equipment (Shimadzu, XRD-6000) operating with a copper $\mathrm{K} \alpha$ radiation of $40 \mathrm{kV}, 30 \mathrm{~mA}$ current, and wavelength $\lambda=1.5406 \AA$. The analyses were performed with dry samples and samples treated with ethylene glycol. The samples were analyzed using a $2 \theta$ between $3^{\circ}-70^{\circ}$ where the rate of the goniometer was set to $2 \% \mathrm{~min}$. Crystalline phases were identified using ICDD PDF file numbers: 12-0219 - smectite; 43-0685 - illite; 78-2109 - kaolinite; 05-0586 - calcite; 89-8575 - feldspar; and 46-1045 - quartz.

The disintegration test was developed by the petroleum 
industry to simulate the impacts of cuttings (shale fragments) on the drill string. These impacts promote the disintegration of the fragments, i.e. dispersion. The disintegration test was performed according to the ISO 10416:2008 standard [13]. The equipment used to carry out the test was a roller oven (Fann, 704 ES), composed of stainless-steel cells with a capacity of $400 \mathrm{~mL}$. For the disintegration tests, the shale samples were milled and sieved between ABNT No. 4 and 8 sieves, with apertures between 4.75 and $2.36 \mathrm{~mm}$, respectively. In this test, three aqueous systems were used: deionized water, aqueous solution of potassium citrate, and drilling fluid. Tables II and III present the concentration of the additives for the aqueous solution of potassium citrate and for the drilling fluid, respectively. The formulation of the drilling fluid used was proposed in [14]. A cell containing $350 \mathrm{~mL}$ of the respective fluid was placed in the roller oven, and then $20 \mathrm{~g}$ of the previously prepared sample of shale (milled and sieved) was added. The rotation speed of the cells was $50 \mathrm{rpm}$ and the temperature of the oven was $150{ }^{\circ} \mathrm{F}$. Those conditions were maintained for $16 \mathrm{~h}$. After $16 \mathrm{~h}$ in the oven, the samples were cooled to room temperature. The cell content (fluid+shale) was carefully filtered in a No. 200 ABNT sieve and washed with a flow of fresh water at approximately $2 \mathrm{~L} / \mathrm{min}$. The shale particles with a size lower than $0.074 \mathrm{~mm}$ were not retained in the sieve and were considered dispersed. The material retained in the sieve was then put into an oven. There, the material was subjected to a temperature of $140^{\circ} \mathrm{F}$ for $24 \mathrm{~h}$. After this time, the material was weighed in a high precision analytical balance. Eq. C provides the disintegration of the sample tested:

Table II - Formulation of the aqueous solution of potassium citrate.

[Tabela II - Formulação para solução aquosa de citrato de potássio.]

\begin{tabular}{ccc}
\hline Additive & Function & $\begin{array}{c}\text { Concentration } \\
(\mathrm{g} / 350 \mathrm{~mL} \text { of water })\end{array}$ \\
\hline $\begin{array}{c}\text { Potassium } \\
\text { citrate }\end{array}$ & $\begin{array}{c}\text { Swelling } \\
\text { inhibitor }\end{array}$ & 20.0 \\
\hline
\end{tabular}

$$
\mathrm{D}=\frac{\left(\mathrm{m}_{\mathrm{i}}-\mathrm{m}_{\mathrm{r}}\right) \cdot 100}{\mathrm{~m}_{\mathrm{i}}}
$$

where $\mathrm{D}$ is disintegration rate $(\%), \mathrm{m}_{\mathrm{i}}$ is the initial mass of the sample $(\mathrm{g})$ and $\mathrm{m}_{\mathrm{r}}$ is the mass of shale retained in the sieve $(\mathrm{g})$.

\section{RESULTS AND DISCUSSION}

The cation exchange capacity (CEC) of a clay mineral is the ability to absorb cations into its molecular structure [15]. For shale formations, this property reflects the level of reactivity in an aqueous fluid [16]. The higher the CEC, the more reactive the shale is, where this particular behavior has been observed in smectite [17]. Fig. 1 presents the values of CEC and specific surface area (SSA) for all samples analyzed. According to Stephens et al. [16], rocks with CEC values greater than $20 \mathrm{meq} / 100 \mathrm{~g}$ are classified as being highly reactive and are termed swelling rocks. Values ranging between $10-20 \mathrm{meq} / 100 \mathrm{~g}$ are considered to have medium reactivity and rocks with values lower than 10 $\mathrm{meq} / 100 \mathrm{~g}$ are considered to not swell. The results presented in Fig. 1 show a cation exchange capacity between 18.5 and $37.0 \mathrm{meq} / 100 \mathrm{~g}$ when using dry clay for the shale samples. For the sodium bentonite sample (SB), the cation exchange capacity was $92.5 \mathrm{meq} / 100 \mathrm{~g}$ when using dry clay. Using the previous definition [16], samples S1 and S4 were classified as having medium reactivity, while samples S2, S3, and S5 were highly reactive. Table IV presents the values of CEC and SSA for different clay minerals, according to [18]. Comparing the results from Figs. 1 and 2 to the typical values found in Table IV, it can be inferred that the samples of shale contained a considerable amount of illite, whereas the sodium bentonite clay was primarily composed of smectite. It is important to note that these results did not indicate the absence of other minerals in the studied samples as finegrained minerals, such as quartz, which have associated CEC values and influence the measured values [19]. In regards to the measured SSA, the shale samples presented values ranging from $144.4 \mathrm{~m}^{2} / \mathrm{g}$ (S1 and S4) to $288.9 \mathrm{~m}^{2} / \mathrm{g}$ (S2), while the SB sample value was $721.9 \mathrm{~m}^{2} / \mathrm{g}$. It may be understood that the higher the SSA, the greater the area for hydration and probable swelling.

Table III - Formulation of the inhibitive drilling fluid.

[Tabela III - Formulação do fluido de perfuração inibido.]

\begin{tabular}{ccc}
\hline Additive & Function & Concentration $(\mathrm{g} / 350 \mathrm{~mL}$ of water $)$ \\
\hline Silicone based fluid & Defoamer & 0.084 \\
Xanthan gum & Viscosifier & 1.5 \\
Low viscosity carboxymethyl cellulose & Filtrate reducer & 3.5 \\
Magnesium oxide & pH controller & 1.0 \\
Potassium citrate & Swelling inhibitor & 20.0 \\
Tetrakis(hydroxymethyl)phosphonium & Bactericide & 0.7 \\
Calcite & Sealing agent & 15.0 \\
\hline
\end{tabular}



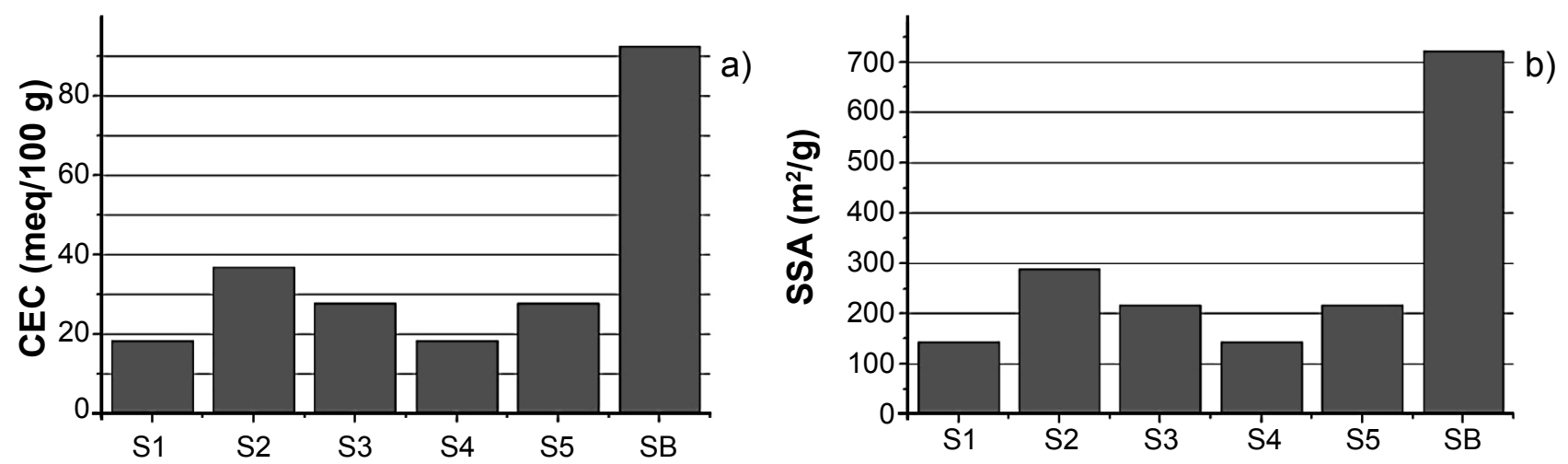

Figure 1: Cation exchange capacity (a) and specific surface area (b) of the samples.

[Figura 1: Capacidade de troca de cátions (a) e área superficial específica (b) das amostras estudadas.]

Table IV - CEC and SSA values for the main clay minerals, according to [18].

[Tabela IV - Valores de CTC e ASE dos principais argilominerais, de acordo com [18].]

\begin{tabular}{ccc}
\hline Clay mineral & $\begin{array}{c}\text { CEC } \\
\text { (meq/100 g of dry clay) }\end{array}$ & $\begin{array}{c}\text { SSA } \\
\left(\mathrm{m}^{2} / \mathrm{g}\right)\end{array}$ \\
\hline Kaolinite & $3-15$ & $5-10$ \\
Illite & $10-40$ & $100-200$ \\
Vermiculite & $100-150$ & $300-500$ \\
Smectite & $80-150$ & $700-800$ \\
\hline
\end{tabular}

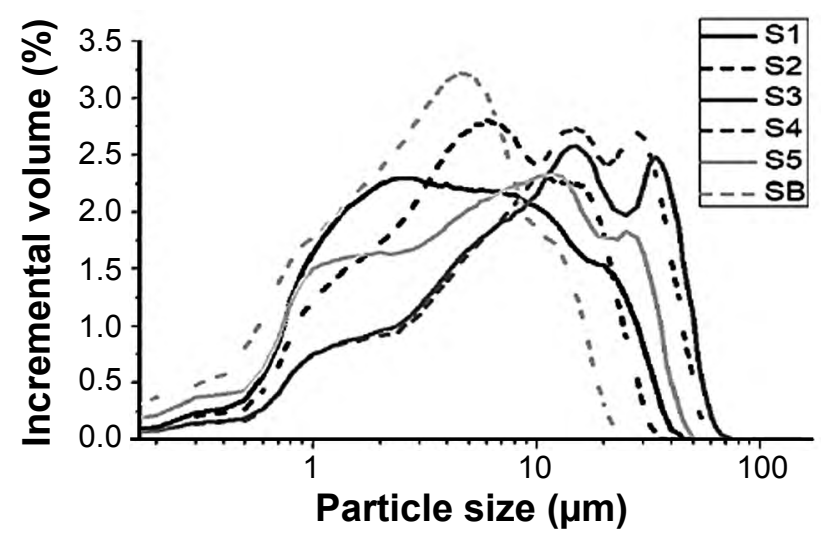

Figure 2: Particle size distribution curves of the samples.

[Figura 2: Curvas de análise granulométrica das amostras.]
Fig. 2 and Table V present the results of the particle size analysis by laser diffraction of the shale samples. It can be seen that the samples presented a large and multimodal distribution which was more pronounced in samples S1, S2 and SB. The concentration of the particles in the samples ranged from 6.97 to $18.57 \mu \mathrm{m}$ for $\mathrm{S} 1,6.75$ to $16.27 \mu \mathrm{m}$ for $\mathrm{S} 2,13.97$ to $34.62 \mu \mathrm{m}$ for $\mathrm{S} 3,13.27$ to $30.95 \mu \mathrm{m}$ for $\mathrm{S} 4,8.39$ to $22.60 \mu \mathrm{m}$ for $\mathrm{S} 5$, and 4.52 to $10.77 \mu \mathrm{m}$ to $\mathrm{SB}$, having an average particle size varying from 4.52 to $13.97 \mu \mathrm{m}$. The volume fraction of samples presenting diameters smaller than $2 \mu \mathrm{m}$ was $31.67 \%, 25.39 \%, 16.37 \%, 15.81 \%, 30.26 \%$, and $35.31 \%$ for samples S1 to S5 and SB, respectively. In short, based on Table $\mathrm{V}$, it is possible to observe that the shale samples had a volume of particles smaller than 2 $\mu \mathrm{m}$ varying between $15.81 \%$ (S4) and $31.67 \%$ (S1), thus indicating the presence of considerable clay contents in their compositions.

Table VI shows the results of the chemical compositions of the samples assessed by the X-ray fluorescence (XRF) technique. Analyzing Table VI, it was verified that samples $\mathrm{S} 1$ and $\mathrm{S} 5$ presented high content of $\mathrm{SiO}_{2}(53.24 \%$ and $53.87 \%$, respectively), followed by a high $\mathrm{Al}_{2} \mathrm{O}_{3}$ content $(21.09 \%$ and $19.54 \%$, respectively), which may be indicative of the presence of quartz and clay minerals. The content of $\mathrm{Fe}_{2} \mathrm{O}_{3}$ was $8.59 \%$ and $10.44 \%$, respectively. These samples also exhibited the presence of $\mathrm{K}_{2} \mathrm{O}(3.60$ and $3.64 \%$, respectively), indicating the presence of illite. Sample S2 presented high contents of $\mathrm{SiO}_{2}(52.75 \%)$ and

Table V - Parameters obtained in the particle size characterization of the shale samples.

[Tabela V - Parâmetros obtidos na caracterização granulométrica das amostras de folhelhos.]

\begin{tabular}{cccccc}
\hline Sample & $\begin{array}{c}\text { Average diameter } \\
(\mu \mathrm{m})\end{array}$ & $\begin{array}{c}\text { Diameter at } 10 \% \\
(\mu \mathrm{m})\end{array}$ & $\begin{array}{c}\text { Diameter at } 50 \% \\
(\mu \mathrm{m})\end{array}$ & $\begin{array}{c}\text { Diameter at } 90 \% \\
(\mu \mathrm{m})\end{array}$ & $\begin{array}{c}\text { Fraction of particles }<2 \mu \mathrm{m} \\
(\text { wt } \%)\end{array}$ \\
\hline S1 & 6.97 & 0.81 & 3.82 & 18.57 & 31.67 \\
S2 & 6.75 & 0.90 & 4.71 & 16.27 & 25.39 \\
S3 & 13.97 & 1.19 & 9.74 & 34.62 & 16.37 \\
S4 & 13.27 & 1.23 & 10.00 & 30.95 & 15.81 \\
S5 & 8.39 & 0.67 & 4.91 & 22.60 & 30.26 \\
SB & 4.52 & 0.61 & 3.21 & 10.77 & 35.31 \\
\hline
\end{tabular}


$\mathrm{Al}_{2} \mathrm{O}_{3}(18.78 \%)$. The content of $\mathrm{Fe}_{2} \mathrm{O}_{3}$ was in the range of $6 \%$ to $9 \%$, indicating the presence of illite in its composition. Analyzing samples S3 and S4, relatively lower levels of $\mathrm{SiO}_{2}\left(38.15 \%\right.$ and $39.86 \%$, respectively) and $\mathrm{Al}_{2} \mathrm{O}_{3}(14.18 \%$ and $14.86 \%$, respectively) were observed when compared to the values obtained for the other samples. However, even at lower percentages, they indicated the presence of quartz and clay minerals. The presence of $\mathrm{CaO}(14.31 \%$ and $22.79 \%$, respectively) indicated the presence of calcite $\left(\mathrm{CaCO}_{3}\right)$. These were the highest values of calcium oxides found in all samples studied. The presence of calcite in these samples may be related to the fact that during the formation of the Araripe Basin there was sea water present. The $\mathrm{MgO}$ content $(4.13 \%$ and $5.41 \%$, respectively) may indicate the presence of smectite clay, kaolinite or illite.

Fig. 3 shows the X-ray diffraction (XRD) patterns of the samples studied. XRD tests were performed on the samples with and without the presence of ethylene glycol. When there was ethylene glycol, EG was added to the nomenclature. According to the diffractograms presented in Fig. 3a, there are peaks indicating the presence of illite, kaolinite, calcite, feldspar and quartz in samples S1 and S5. The peaks observed in samples S2, S3 and S4 indicated the presence of smectite, illite and kaolinite, in addition to the presence of calcite, quartz and feldspar, as observed on the diffractograms shown in Fig. 3b. The diffractogram for the sample of the sodium bentonite clay (Fig. 3c) exhibited peaks related to clay minerals of the smectite group and peaks referring to the presence of quartz and feldspar. The diffractograms confirmed the presence of illite in all the shale samples. In addition, the results of the XRD together with the values of the CEC and SSA showed illite to be the predominant clay mineral. For the SB sample, those results indicated the predominance of smectite. To aid in the identification of the different clay minerals present, Table VII contains the mineralogical components of each sample studied.

Fig. 4 shows the disintegration rate values for the shale samples (S1-S5) and sodium bentonite (SB) in three aqueous systems. The dispersed percentage measured in deionized water was, for most samples, higher than for the other fluids. For most of the samples, it could be concluded that the inclusion of potassium citrate provided a stabilizing effect and reduced the potential of disintegration. Comparing the results of CEC, XRD and disintegration rate in deionized water, the resulting trends suggested that the disintegration phenomenon occurred whether or not reactive clay minerals were predominantly present and higher reactivity did not necessarily imply higher disintegration levels. Sample S1 presented the lowest value of CEC and SSA among the shale samples and the XRD results showed the absence of smectite in its composition. Thus, considering the swelling of the smectites as the main mechanism of instability, this sample should present the lowest disintegration rate. However, the disintegration rate of $\mathrm{S} 1$ in deionized water was found to be $20.43 \%$. Samples S2 and S3, which had higher values of CEC

Table VI - Chemical compositions (wt\%) of the studied samples.

[Tabela VI - Composições químicas (\% em massa) das amostras estudadas.]

\begin{tabular}{cccccccccccc}
\hline Sample & $\mathrm{SiO}_{2}$ & $\mathrm{Al}_{2} \mathrm{O}_{3}$ & $\mathrm{Fe}_{2} \mathrm{O}_{3}$ & $\mathrm{~K}_{2} \mathrm{O}$ & $\mathrm{MgO}$ & $\mathrm{TiO}_{2}$ & $\mathrm{MnO}$ & $\mathrm{SO}_{3}$ & $\mathrm{P}_{2} \mathrm{O}_{5}$ & $\mathrm{CaO}$ & $\mathrm{Na}_{2} \mathrm{O}$ \\
\hline $\mathrm{S} 1$ & 53.24 & 21.09 & 8.59 & 3.60 & 4.00 & 0.95 & 0.11 & 0.15 & 0.05 & 3.34 & 4.70 \\
$\mathrm{~S} 2$ & 52.75 & 18.78 & 7.25 & 4.92 & 4.61 & 0.82 & 0.06 & 1.93 & 0.72 & 7.82 & - \\
$\mathrm{S} 3$ & 38.15 & 14.18 & 10.67 & 4.13 & 3.30 & 0.68 & 0.10 & 13.71 & 0.60 & 14.31 & - \\
$\mathrm{S} 4$ & 39.86 & 14.86 & 7.56 & 5.41 & 3.55 & 0.89 & 0.10 & 4.74 & - & 22.79 & - \\
$\mathrm{S} 5$ & 53.87 & 20.54 & 10.44 & 3.64 & 3.71 & 1.05 & 0.12 & 0.12 & 0.13 & 3.98 & 2.23 \\
$\mathrm{SB}$ & 65.21 & 17.86 & 8.93 & 0.44 & 2.67 & 0.92 & 0.03 & 0.21 & - & 1.56 & 2.03 \\
\hline
\end{tabular}
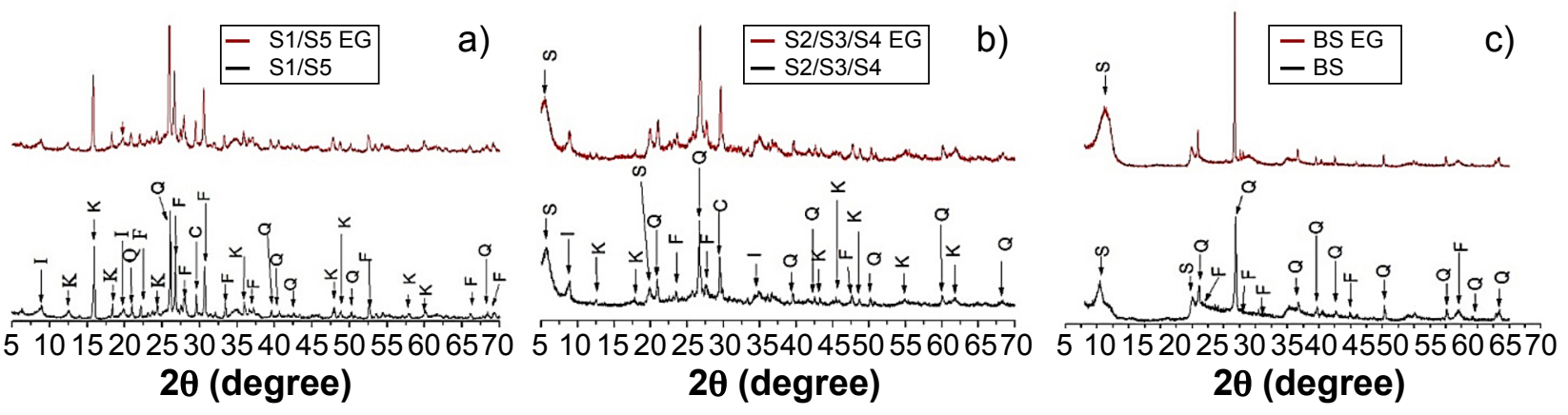

Figure 3: X-ray diffraction patterns of samples S1 and S5 (a), S2, S3 and S4 (b), and SB (c) in the presence (EG) and absence of ethylene glycol. S-smectite, I-illite, K-kaolinite, C-calcite, Q-quartz, F-feldspar.

[Figura 3: Difratogramas de raios X para as amostras $S 1$ e $S 5($ a), S2, S3 e $S 4$ (b) e SB (c) na presença (EG) e ausência de etileno glicol. $S$-esmectita, I-ilita, K-caulinita, C-calcita, Q-quartzo, F-feldspato.] 
Table VII - Mineralogical components of the analyzed samples.

[Tabela VII - Componentes mineralógicos presentes nas amostras estudadas.]

\begin{tabular}{ccccccccc}
\cline { 2 - 7 } & Sample & Smectite & Illite & Kaolinite & Calcite & Quartz & Feldspar \\
\cline { 2 - 7 } S1 & - & X & X & X & X & X \\
S2 & X & X & X & X & X & X \\
S3 & X & X & X & X & X & X \\
S4 & X & X & X & X & X & X \\
S5 & - & X & X & X & X & X \\
SB & X & - & - & - & X & X \\
\hline
\end{tabular}

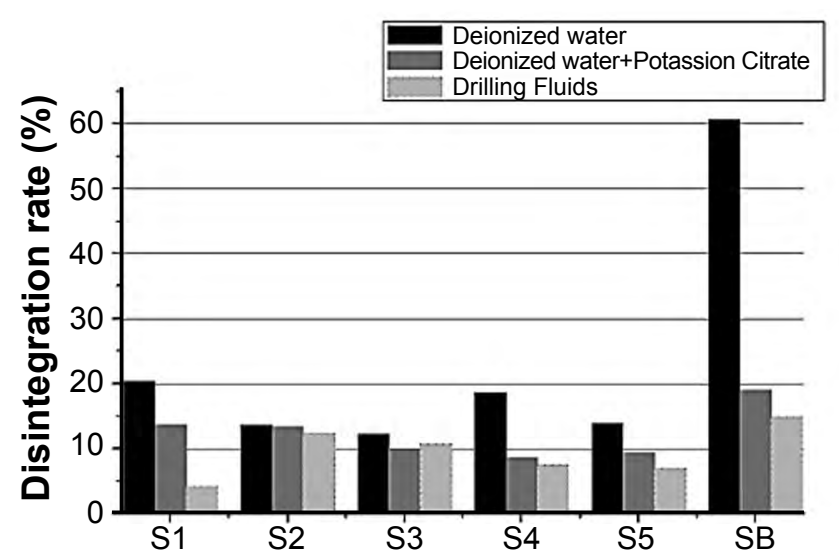

Figure 4: Disintegration rate of the samples in different aqueous systems.

[Figura 4: Taxa de desintegração das amostras em diferentes sistemas aquosos.]

and SSA and were found to contain smectite according to the XRD results, presented lower disintegrated rates $(13.60 \%$ and $12.15 \%$, respectively) which were approximately $33 \%$ and $41 \%$, respectively, smaller than $\mathrm{S} 1$. When comparing samples S1 and S5, which presented the same mineralogical composition, the values of CEC and SSA for sample S5 were higher than those found in sample S1. However, in spite of being considered more reactive, the disintegration of S5 in deionized water was approximately $32 \%$ lower than S1. Comparing samples S2, S3 and S4, which presented the same mineralogical composition, the results again suggested that the higher reactivity of shale formations in aqueous fluids did not necessarily imply higher disintegrated rates. However, samples S2 and S3 presented CEC and SSA values higher than $\mathrm{S} 4$ while exhibiting lower disintegrated rates, where S2 and S3 had approximately $27 \%$ and $35 \%$ lower disintegrated rate in comparison to $\mathrm{S} 4$.

Analyzing the disintegration results with the results of granulometric analysis (GA), it was possible to verify that the samples with the highest percentage of particles smaller than $2 \mu \mathrm{m}$ showed higher disintegration rate when tested in deionized water. With respect to the results obtained by the $\mathrm{XRF}$, it was possible to affirm that shales with higher $\mathrm{CaO}$ contents had lower values of disintegration. In addition, illite containing shales (samples S1 and S5) showed higher disintegration rate when compared to smectite containing shales (S2, S3 and S4). This behavior may be related to

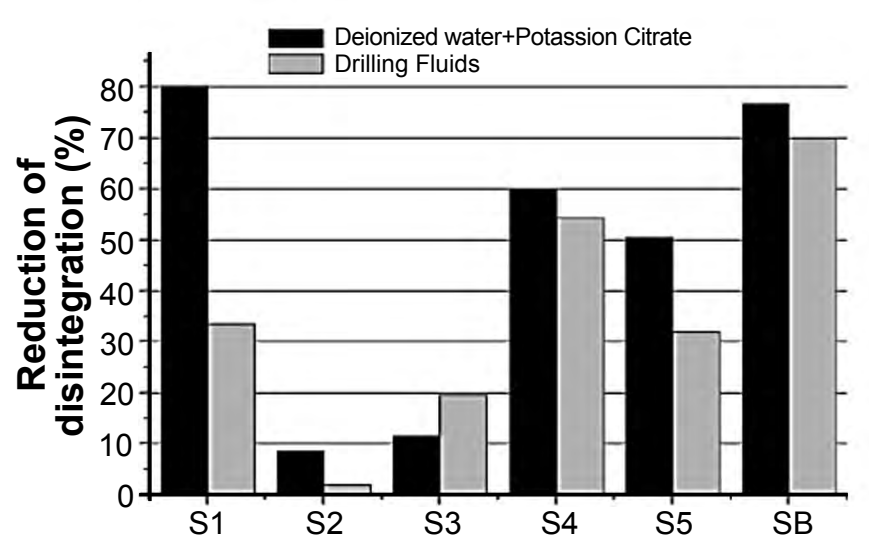

Figure 5: Reduction of disintegration in inhibited fluids. [Figura 5: Redução da desintegração em fluidos inibidos.]

the presence of $\mathrm{CaO}$ that acted as a cement, making the disintegration difficult. In view of this, it was evident that a higher level of reactivity in the presence of aqueous fluid did not necessarily imply a higher disintegration. These results also highlighted the importance of the presence of an instability mechanism unrelated to swelling. As discussed in [6], shales rich in illite and kaolinite may also be unstable. According to the authors, the greater thickness of the diffuse double layer (DDL) of the illite, when compared to the smectite, implies a greater force of separation between layers of the clay minerals. This feature, associated with the micropore structure of shale and its compaction history, might have resulted in high pore pressures and unstable behavior.

Fig. 5 shows the reduction in disintegration while using deionized water with potassium citrate and drilling fluids when compared to the disintegration measured in deionized water. The swelling inhibitor (potassium citrate) was efficient in inhibiting the disintegration of the samples. With the exception of sample S3, the largest reductions in disintegration were observed when the samples were tested with deionized water containing potassium citrate. The largest reduction was verified for sample S1 (80.20\%), while the smallest was observed in sample S2 (8.82\%). According to [11], potassium salts have a great effect on the swelling of smectites, but a minor effect on the illites. Following this thought, samples S1 and S5, which contained no smectite, 
should show a minimal reduction in disintegration with the potassium citrate containing fluid but instead showed a greater reduction of disintegration than samples S2 and S3 which contained smectite. These results emphasized that the instabilities of clays were not directly connected to swelling and implied that there were other instability mechanisms. Additionally, the results showed that, depending on the shale formation, these instability mechanisms contribute at different amounts, sometimes more, other times showing smaller contributions, to the total instability of the clay formation.

\section{CONCLUSIONS}

The shale samples from the Rio do Peixe and Araripe Basins were considered to have a medium and high reactivity potential, while the sample of sodium bentonite clay presented a high potential. The disintegration behavior of the analyzed shales presented considerable disintegration rates when in the presence of deionized water, but had reduced disintegration when in the presence of the potassium citrate salt. It was shown that shale formations that do not exhibit reactive clay minerals may be unstable and that the higher the reactivity of a formation to an aqueous fluid does not necessarily imply greater disintegration. Also, in regards to disintegration, it was concluded that the samples with lower $\mathrm{CaO}$ contents showed more instability in terms of disintegration. Therefore, different mechanisms not associated with the swelling of clay minerals may assume more or less importance in the unstable behavior of shale formations drilled with aqueous fluids.

\section{ACKNOWLEDGMENTS}

The authors thank the Petroleum National Agency (ANP), the Human Resources Program PRH-42 and CAPES for the financial support and granting of scholarships, the Company Bentonit União Nordeste for the supply of bentonite clay and PeFLab for the use of its physical facilities.

\section{REFERENCES}

[1] K. Suguio, Geologia sedimentar, Edgard Blücher, S. Paulo (2003).

[2] G. Nichols, Sedimentology and stratigraphy, $2^{\text {nd }}$ ed., Wiley-Blackwell, Oxford (2009).

[3] G. Chen, M.E. Chenevert, M.M. Sharma, M. Yu, J. Pet. Sci. Eng. 38 (2003) 167.

[4] C. Yan, J. Deng, B. Yu, Sci. World J. 2013 (2013) 720271. [5] J.J. Azar, G.R. Samuel, Drilling engineering, PennWell Books, Oklahoma (2007).

[6] M.J. Wilson, L. Wilson, Clay Miner. 49 (2014) 127.

[7] M.E. Chenevert, J. Pet. Technol. 22 (1970) 1309.

[8] N. Gaurina-Medjimurec, B. Pasic, in "Risk analysis for prevention of hazardous situations in petroleum and natural gas engineering", IGI Global, Hershey (2013) 23.

[9] G.M. Bol, S.-W. Wong, C.J. Davidson, D.C. Woodland, SPE 24975 PA, SPE 9 (1994) 87.

[10] M. Lal, in: Lat. Am. Carib. Pet. Eng. Conf. (1999).

[11] E. Van Oort, J. Pet. Sci. Eng. 38 (2003) 215.

[12] M.J. Wilson, L. Wilson, M.V. Shaldybin, Spec. Publ., Geol. Soc., London. 454 (2017) 253.

[13] "Shale-particle disintegration test by hot rolling section 23", API (2009).

[14] D.V. Lucena, C.M.R.A. Souto, H.L. Lira, L.V. Amorim, Tecnol. Metal. Mater. Miner. 11 (2014) 355.

[15] R. Dohrmann, Appl. Clay Sci. 34 (2016) 31.

[16] M. Stephens, S. Gomes-Nava, M. Churan, in Nat. Techn. Conf. Exhib., AADE 2009-NTCE-11-04, Am. Ass. Dril. Eng., Lousiana (2009).

[17] J. Srodon, Clay Miner. 44 (2009) 421.

[18] P. Souza Santos, Ciência e tecnologia de argilas, vol. 1, $2^{\mathbf{a}}$ ed., Edgard Blücher, S. Paulo (1989).

[19] M. Asef, M. Farrokhrouz, Shale engineering: mechanics and mechanisms, CRC Press, Boca Raton (2013).

(Rec. 13/11/2018, Rev. 05/02/2019, 18/03/2019, Ac. 21/03/2019) 